\title{
ARE INDUSTRIES RESPONDING DIFFERENTLY TO THE EMPLOYMENT EQUITY CHALLENGE?
}

\author{
HELENA SMITH \\ GERT ROODT \\ Department of Human Resource Management \\ Rand Afrikaans University
}

\begin{abstract}
The primary objective of the study was to determine whether the Employment Equity Questionnaire detects significant differences between employment equity practices of companies from different industries in order to assess the discriminant validity of the scale. Samples of convenience from nine different companies representing different industries, constituted a larger sample of 4729. First and second level factor analyses on 41 common items across all nine companies yielded a single scale with an acceptable Alpha coefficient of 0,959 . Analysis of variance, followed by post hoc contrast tests, indicated significant differences between some organisations. The discriminant validity of the scale could be established and recommendations for further improvement of the scale were made.
\end{abstract}

\section{OPSOMMING}

Die doel van die studie was om te bepaal of die "Employment Equity Questionnaire" betekenisvolle verskille kan uitwys tussen die werkgelykheidspraktyke van maatskappye vanuit verskeie industrieë ten einde die diskriminante geldigheid van die instrument te bepaal. Gerieflikheidsteekproewe van nege verskillende maatskappye, verteenwoordigend van verskillende industrieë, het 'n totale steekproef van 4729 daargestel. Eerste en tweede vlak faktorontledings is op 41 gemeenskaplike items oor al nege maatksappye gedoen en dit het 'n aanvaarbare Alfa koëffisiënt van 0,959 opgelewer. 'n Variansie-ontleding, gevolg deur post hoc kontrastoetse, het op betekenisvolle verskille tussen die onderskeie organisasies gedui. Die diskriminante geldigheid van die instrument kon vasgestel word en aanbevelings ter verbetering daarvan is aan die hand gedoen.

The South African government has visibly demonstrated its intention to deal with the problem of inequality and discrimination in the workplace, bringing about a diverse workforce representative of South Africa's demographics. The Employment Equity Act, 1998 (Act No. 55 of 1998), together with the Labour Relations Act, 1995 (Act No. 66 of 1995), the Basic Conditions of Employment Act, 1997 (Act No. 75 of 1997), and the Skills Development Act, 1998 (Act No. 97 of 1998) are but a few of the regulations put in place to achieve these objectives.

The Employment Equity Act was promulgated in 1998 and the purpose of this Act is "to achieve equity in the workplace by -

a) promoting equal opportunity and fair treatment in employment through the elimination of unfair discrimination, and

b) implementing affirmative action measures to redress the disadvantaged in employment experienced by designated groups, in order to ensure their equitable representation in all occupational categories and levels in the workforce". In terms of the Act, designated groups mean black people, women and people with disabilities" (1998, p. iv).

Four years have passed since the promulgation of the Act, given ample time for the introduction and implementation of the principles and requirements within the working environment. Adherence to and the implementation of the requirements were however received with mixed feelings by industry. Employers identified various factors; legacy issues, business processes, corporate culture, skills scarcity and financial constraints as restrictive factors hindering optimal realization/attainment of the objectives (Commission for Employment Equity Annual Report, 2001). The annual Employment Equity Report for the period May 1999 to June 2001 revealed that many employers responded positively to the initiatives, seeing it as part of the overall strategic positioning of the business. On the other hand, the report has shown that workplace segregation along race and gender lines still exists, with a huge under representation of black people and women in top and senior management. It thus seems as if the process of implementation didn't occur at the same pace in all industries nor perceived by all in a similar fashion.

Requests for copies should be addressed to: H Smith, Department of Human Resource Management, RAU University, PO Box 524, Auckland Park, 2006
In this regard Human (2000) pointed out that the Employment Equity Act (1998) requires a fundamental change in the way we think about and perceive people and if this doesn't take place, the implementation of an Employment Equity strategy will remain problematic. Swanepoel, Erasmus, Van Wyk and Schenk (2000, p. 157) agreed, pointing to the fact that "laws can require organisations to hire and promote historically disadvantaged individuals, the law however cannot remove societal barriers arising from people's attitudes". In this instance, competing views of the relationship between individuals and broad society can have profound implications on each other's view of equity and equality. Strict adherence to the regulations alone is thus not sufficient if a company wants to attain success in this area. According to Human, good employment equity is part and parcel of good people management and "good people management leads to increased productivity" (http://www.csls.org.za/dw/art3c.html).

\section{The Employment Equity Questionnaire}

In accordance with the Act, the compilation of an Employment Equity audit is required to determine the current status quo, to identify disparities and it also forms part of the annual Employment Equity report. Against this backdrop, companies are confronted with the dilemma of effective and reliable measurement of their progress up to date in order to determine the extent of adherence to the regulations. Attempts have been made to develop measurement instruments, ranging from simple checklists, interviews, rapid audits to comprehensive and structured questionnaires (Sacht, 2001). The results of such an audit will enable companies to assess whether the required policies, practices and procedures exist and to what extent it is being enforced. Such a questionnaire to appraise Employment Equity practices in a company, named the Employment Equity Questionnaire, was compiled by Organisational Diagnostics in association with Ernest \& Young and was presented to different companies to complete. This instrument focussed on determining the degree of compliance and can be considered as being context specific.

The conducting of an audit by means of a questionnaire is a widely used and acceptable practice, given that the questionnaire complies to requirements of sound construct 
compilation to ensure optimal validity and reliability. It is therefore essential to take cognisance of the principles and criteria underpinning questionnaire construction, as it will impact on the quality of the measuring instrument that will be used and the data obtained. In this regard, the criteria and work method identified by Schepers (1992) will be used as guideline in assessing the Employment Equity Questionnaire.

Bailey (1982, p. 113) stated that the key word in questionnaire construction is "relevance", paying particular attention to "(the) relevance of the study's goals, (the) relevance of the questions to the goals of the study and (the) relevance of the questions to the individual respondent". Schepers (1992) agreed, stating that at the outset the construct (Employment Equity) should be theoretically founded. In this respect, equality in the workplace entails "the systematic identification and removal of underlying causes of discrimination in order to give persons, or categories of persons, equal opportunities" (Watkins, 2002, p. 18).

Care should therefore to be taken to ensure that the questions posted, adequately measure the theoretical concept, and that the sample of respondents answer the questions adequately. This statement presumes that the questionnaire as measuring instrument will be valid. Bailey (1982, p. 68) quoted Selltiz, who defined the validity of a measuring instrument as the "extent to which differences in scores on it reflect true differences among individual on the characteristics we seek to measure". This implies that the questionnaire measures the concept in question and that the concept is being measured accurately. Reliability of an instrument in turn points to the consistency of measurements. As stated by Bailey (1982, p. 73) "a measure is reliable if the measurement doesn't change when the concept being measured remains constant in value" and "if the concept being measured does change in value, a reliable measure will indicate that change".

According to Schepers (1992), the second issue in questionnaire construction encompasses the domain upon which the construct applies. In this respect, the domain is that of Employment Equity practices, as demonstrated in the overall focus of the Act being the removal of barriers for those previously denied access to jobs, appointments and developmental opportunities in the workplace. This requires ascertaining fairness and equitability in employment practices in order to ensure equality for all employees through the implementation of non-discriminatory policies and practices (Sacht, 2001). In relation to this, Human and Dentin (1997, p.1) noted "affirmative action imperatives are often not supported by organisational structures such as policies and procedures". From this it is clear that the implementation of Employment Equity practices would touch on all human resource (HR) functions/areas as well as policies and procedures in organisations. In order to measure compliance with legislation, as well as the progress of implementation, each of these areas, with its associated policies and principles, need to be covered in an audit. The scope of a thorough and comprehensive Employment Equity audit thus goes beyond a mere ticking of a list, it has to cover an array of HR areas. This is in agreement with De Beer and Clow (2001, p.32), who have advised that an employment equity questionnaire should include the following categories; "personal information, equality, performance and pay, recruitment and development, policies and procedures, employee welfare and participation and affirmative action". According to Human (2002, p.2), research, and the auditing of many large organisations with respect to people management, have indeed revealed that the "development and promotion opportunities, performance management, managerial attitudes towards race, gender diversity and human dignity, the eradication of discrimination and the development of potential" are areas of dissatisfaction amongst employees.

The various HR areas that have to be covered in an audit can collectively be grouped under three major functions; Provision, Maintenance and Training and Development (Carrell, Elbert, Hatfield, Grobler, Marx, \& Van Der Schyf (1998), Gerber, Nel and
Van Dyk (1995), and Sacht (2001)). Each of these three functions consists of various sub-functions, with policies and principles underpinning all as demonstrated in figure 1. Employment Equity practices within all of these three functions, as well as the sub-functions, need to reflect fairness and equity both in the compilation of and addressing of practices, resulting in equitable participation of designated groups. This ties in with the third aspect described by Schepers (1992), where the sub-domains need to be identified, being the various HR sub-functions.

\begin{tabular}{|l|l|l|}
\hline Provision & Maintenance & $\begin{array}{l}\text { Training \& } \\
\text { development }\end{array}$ \\
\hline \multicolumn{2}{|c|}{ POLICIES AND PROCEDURES } \\
\hline
\end{tabular}

Figure 1: Human Resource function in organisations

Fourthly, Schepers (1992) indicated that these identified subdomains need to be operationalised and described in observable terms or behavioural indicators. These behavioural indicators are used to merge the theoretical concepts and the empirical variables with each other. For illustrative purposes, a few questions from the Employment Equity Questionnaire will be added to illuminate the sub-domain of concern. Within a formal questionnaire, four to five questions will be designed to comprehensively assess each sub-domain ensuring that both the construct as well as the domain is covered.

\section{Provision:}

This is the first phase in the HR process and consists of paving the way for the organisation to equip itself with employees. Affirmative action measures should be in place, visibly demonstrating the company's intention to redress disadvantages in employment and ensuring equitable representation in all occupational categories and levels in the workplace. In the analysis of the job, the compilation of job descriptions, recruitment advertisements, selection procedures and induction, practices or factors should be followed that positively promote Employment Equity and diversity in the workplace. In these procedures there should be no practices that could be seen as biased, inappropriate or unsupportive of Employment Equity. All of the HR functions pertaining to provision may not in any way discriminate against any employee on any grounds identified by the relevant legislation.

- Job analysis being the "process by which management systematically investigates the tasks, duties and responsibilities of the jobs within an organisation. The process includes investigating the level of decision-making by employees within a job category, the skills employees need to do a job adequately, the autonomy of the job in question and the mental effort required to perform the job" (Carrell et al., 1998, p. 78). Machines operated, working conditions and other specific responsibilities must be included in the analysis of the job. The end result of the job analysis is a job description, which is used in the recruitment process as well as in job evaluation upon which remuneration decision are taken.

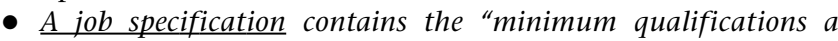
person must have to be considered for the job" (Carrell et al., 1998, p. 97). This would include skills, knowledge and abilities. In SAQA terms, this would refer to unit standards against which competencies are assessed.

- Iob design; defined by Carrell et al. (1998, p. 109) as "the manipulation of the content, functions and relationships of jobs in a way that both accomplishes organisational purposes and satisfies the personal needs of individual job holders".

- HR planning defined by Carrell et al. (1998, p. 142) as "the process of systematically reviewing human resource requirements to ensure that the required number of employees, with the 
required skills are available when they are needed".

- Recruitment is the process of "acquiring applicants who are available and qualified to fill positions in the organisation" (Carrell et al., 1998, p. 138).

- Selection described by (Carrell et al., 1998, p. 17) as the process where "the best suited individual for a particular position is chosen from a group of applicants". It is evident that the criteria used should reflect Employment Equity principles.

- Pre-employment assessment is the process where applicants might be assessed on a variety of interviews and tests, ranging from psychological, knowledge, performance, aptitude and medical tests.

- Appointment is the follow up of the recruitment and selection process and is described as the process where "an individual is placed in a position in the organisation" (Gerber et. al 1995, p. 152).

- Induction being the "process of introducing new employees to the goals of the organisation, its policies and procedures, its values, the co-workers as well as the activities of the tasks to be performed and the equipment to be used" (Carrell et al., 1998, p. 204).

In terms of recruitment, question 17 is presented as example: "In the company, recruitment takes place without discrimination in terms of gender, language group or religion".

\section{Maintenance:}

This process entails strategies to retain and motivate employees to achieve both personal and organisational goals. Equitable practices in all of the HR functions pertaining to maintenance should be enforced in accordance to relevant legislation to ensure that there is no discrimination against employees and that designated employees are managed in an equitable fashion and not excluded from opportunities.

- Performance appraisal and evaluation systems are associated with assessing an employee's job performance as well as providing feedback on the effectiveness of duty performance. It is important that this process should involve "the systematic and equitable collection of performance information" (Ivancevich et al. 1996, p. 203).

- Remuneration/compensation management refers to the complete spectrum of "both extrinsic rewards such as monetary reward (salary, bonuses, incentives) as well as intrinsic rewards such as achieving personal goals, autonomy and more challenging job opportunities" (Carrell et al., 1998, p. 370). Inclusive of extrinsic rewards are the employee benefits (insurance, retirement, medical, leave, recreational) and -services available to employees.

- Terms and conditions of employment, this outlines the specific circumstances of employment and include the psychological contract as defined by Rousseau (1989) "as the individually held beliefs about the terms of the exchange between employer and employee". In the allocation of job assignments, the work environment and access to facilities, no unfair distinctions should be made between employees and work conditions should accommodate cultural or religious differences.

- Promotions occur where an employee is reassigned to a higher-level job and is normally seen as the "recognition of the person's past performance" (Carrell et al., 1998, p. 237). Promotion can include a transfers or relocation to another area or town. Once again this process should not be to the disadvantage of any employee group.

- Terminations of employment e.g. retrenchment, disciplinary practices, demotions and dismissals should be justified and carried out fairly and in accordance with applicable legislation. The nature of dismissals, voluntary terminations and retrenchments of employees from designated groups should be free from internal or external equity related factors contributing to such terminations.

In terms of promotion, question 58 is posed as an example: "The best people irrespective of language group, gender or religion are promoted".
Training and development:

This area covers employee skills and management development as well as training opportunities emphasising the fact that it should be accessible to designated employees and based on the identification of individual training needs and not on assumed group training needs. In addition to the Employment Equity Act, the South African Qualification Authorities Act, 1995 (Act No. 58 of 1995) and the Skills Development Act, 1998 (Act No. 97 of 1998) introduced a new regulatory framework for devising and implementing strategies and plans for improving occupational skills and qualifications of South Africans. HR functions pertaining to training and development may not in any way discriminate against any employee on any grounds identified by the relevant legislations.

- Health education programmes informing all employees on standards of living and not discriminating against people with diseases. This includes practices relating to the management of e.g. HIV/AIDS in the workplace to ensure that people living with diseases are not discriminated against.

- Career management being the process of "designing and implementing goals, plans and strategies that enable $H R$ professional and managers to satisfy workforce needs and allow individual to achieve their career objectives" (Carrell et al., 1998, p. 347). Individual career planning is seen as the process where each employee plans his/her career goals and these decisions should be based on individual strengths and weaknesses. Equity should be reflected in both succession planning for important positions and career management.

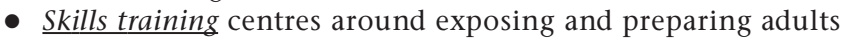
for the performance of tasks relating to specific types of work (Ernst, 2000). This requires a review of training and development methodologies and strategies, including access to training for designated groups, to establish that there are no barriers excluding people to training interventions. Initiatives could include structured training, development programmes such as learnerships and internships, on the job mentoring and coaching, and accelerated training for new inductions.

In terms of training and development, question 46 is posed as example: "Employees of all race groups are assisted by supervisors/managers to develop their full potential".

Once the construct, domain, sub-domains, and behavioural indicators have been described, the fifth aspect of questionnaire design needs to be dealt with. This entails the item and response scale format, linked to and in support of the behavioural indicators (Schepers, 1992). The items of the Employment Equity Questionnaire are posed as individual statements. Research (Kruger \& Roodt, 2003; Swart, Roodt \& Schepers, 1999) indicated that statements tend to generate response distributions that are closely bimodal. Schepers (1992) argued that respondents tend to respond in extreme ways to statements. Questions on the other hand, are inclined to generate response distributions that are closer to a normal curve.

Response scales also play a role in the obtained response patterns. In cases where all the response categories are anchored, the scales are categorical (ordinal/nominal) in nature and lack equal interval properties (Schepers, 1992). Likert type intensity scales on the other hand are only anchored at the extreme poles and do possess equal interval properties. The level of sophistication of the target population normally dictates the choice between a more limited (five-point) or elaborate (sevenpoint) response scale, where the latter tends to enhance the variance explained. A seven-point scale is of value when statistical analysis is to be conducted and in particular when factor analyses are performed. If less than seven intervals are used, the coarse grouping will considerably reduce the correlation between items (Pemberton, 1993; Schepers, 1992; Symonds, 1924). 
A four-point Likert scale was used as the response scale format for the Employment Equity Questionnaire. All response categories were anchored. An example of the response scale used is displayed in figure 2 .

\begin{tabular}{|c|c|c|c|}
\hline Strongly disagree & Disagree & Agree & Strongly agree \\
\hline 1 & 2 & 3 & 4 \\
\hline
\end{tabular}

Figure 2: An example of the response scale used in the Employment Equity questionnaire

\section{Distinctive industry characteristics}

As Employment Equity is being implemented in the South African (SA) industry, this will be the focus of the study. As with any other labour market in the world, the South African labour market also consists of different industries; each with its distinctive characteristics and communities of practice. Stewart described communities of practice as "groups that emerge around a discipline or problem" and are being "defined by the subject that engages them" (2001, p. 2). According to Christensen (1999, p. 1), research indicated that organisations within an industry share "distinct values". These communal values "guide and shape perception and behaviour, impacting on how employees will view its surrounding and how it will react and succeed in the world" (Marquardt, 1998, p. 62). Irani, Sharp and Kagioglou agreed, stating that "employees within a similar industry have a frame of reference within which they pattern their responses" (1997, p. 206). These shared commonalities include observed behavioural regularities, noticeable interaction patterns, shared standards, the use of common language and terminology. These communities of practices evolve over a period of time, providing continuity and stability in an industry and can be described as "a certain style, a character, a way of doing things" (Hellriegel et al., 1998, p. 546). A priori differences between companies' employment equity practises could therefore be postulated on the afore-mentioned grounds. The assumption can therefore be made that companies from the Banking, Chemical, Education, Electronic Media, Information Technology, Motorvehicle manufacturing and Retail industries would respond significantly different to this questionnaire.

The primary objective of the research is to determine if the Employment Equity Questionnaire can detect statistical significant differences on employment equity practices of responding companies from the different industries. This will provide an indication if the measurement can discriminate between the various industries. This will substantiate the discriminant validity of the Employment Equity Questionnaire and indirectly reveal if specific industries were more receptive to equity initiatives than others and have made more progress with the implementation of Employment Equity.

\section{METHOD}

\section{Respondents/Participants}

The unit of analysis is organisations from different industry sectors. Over a short period of time, employees from various organisations from different industries took part in the completion of the questionnaire on their experience of Employment Equity in their respective organisations. In the selection of employees, samples of convenience were drawn from the different organisation populations. Participation was voluntarily and the identity of the respondents was kept anonymous to ensure confidentiality. In order to guarantee authenticity, responsible personnel in each industry distributed and collected the questionnaires. The questionnaire formed part of the organisation's Employment Equity audit and was requested by the organisation.

A total number of 4729 respondents, representative of nine organisations or business divisions, took part in the completion of the questionnaire. The biographical compositions of the groups are according to industries, age, race, language, and gender as depicted in Table 1.

TABLE 1

BIOGRAPHICAL DATA OF THE SAMPLE

\begin{tabular}{|c|c|c|c|}
\hline & Biographical variable & Frequency & $\%$ \\
\hline \multicolumn{4}{|c|}{ Company } \\
\hline \multirow[t]{10}{*}{ Valid } & Electronic media & 549 & 32.8 \\
\hline & Banking & 1055 & 22.3 \\
\hline & Banking & 914 & 19.3 \\
\hline & Vehicle manufacturing & 166 & 3.5 \\
\hline & Retail & 70 & 1.5 \\
\hline & Chemical & 52 & 1.1 \\
\hline & Information technology & 526 & 11.1 \\
\hline & Education & 138 & 2.8 \\
\hline & Information technology & 258 & 5.5 \\
\hline & Total & 4728 & \\
\hline \multicolumn{2}{|c|}{ Missing System } & 1 & \\
\hline \multicolumn{2}{|l|}{ Total } & 4729 & 100 \\
\hline \multicolumn{4}{|l|}{ Age } \\
\hline \multirow[t]{8}{*}{ Valid } & 24 years and younger & 665 & 14.1 \\
\hline & 25 to 30 years & 699 & 19.0 \\
\hline & 31 to 35 years & 649 & 13.7 \\
\hline & 36 to 40 years & 680 & 14.4 \\
\hline & 41 to 45 years & 724 & 15.3 \\
\hline & 46 to 50 years & 614 & 10.9 \\
\hline & 51 years and older & 644 & 11.5 \\
\hline & Total & 4675 & 98.9 \\
\hline \multicolumn{2}{|c|}{ Missing System } & 84 & 1.1 \\
\hline \multicolumn{2}{|l|}{ Total } & 4729 & 100 \\
\hline \multicolumn{4}{|l|}{ Race } \\
\hline \multirow[t]{5}{*}{ Valid } & Black & 1100 & 23.3 \\
\hline & Coloured & 341 & 7.2 \\
\hline & Indian/Asian & 125 & 2.6 \\
\hline & White & 1713 & 36.2 \\
\hline & Total & 3279 & 69.3 \\
\hline \multicolumn{2}{|c|}{ Missing System } & 1450 & 30.7 \\
\hline \multicolumn{2}{|l|}{ Total } & 4729 & 100.0 \\
\hline \multicolumn{4}{|c|}{ Language } \\
\hline \multirow[t]{12}{*}{ Valid } & Afrikaans & 2451 & 51.8 \\
\hline & English & 957 & 20.2 \\
\hline & Ndebele & 41 & 0.9 \\
\hline & North Sotho & 195 & 4.1 \\
\hline & South Sotho & 110 & 2.3 \\
\hline & Swezi & 33 & 0.7 \\
\hline & Tsongo & 115 & 2.4 \\
\hline & Tswana & 435 & 9.2 \\
\hline & Venda & 32 & 0.7 \\
\hline & Zulu & 161 & 3.8 \\
\hline & Other & 30 & 0.6 \\
\hline & Total & 4580 & 96.8 \\
\hline \multicolumn{2}{|c|}{ Missing System } & 149 & 3.2 \\
\hline \multicolumn{2}{|l|}{ Total } & 4729 & 100 \\
\hline \multicolumn{4}{|c|}{ Gender } \\
\hline \multirow[t]{3}{*}{ Valid } & Male & 2296 & 48.5 \\
\hline & Female & 2349 & 49.7 \\
\hline & Total & 4645 & 98.2 \\
\hline \multicolumn{2}{|c|}{ Missing System } & 84 & 1.8 \\
\hline \multicolumn{2}{|l|}{ Total } & 4729 & 100 \\
\hline
\end{tabular}


The age of respondents ranged from 24 years and younger and then from 25 years in five year intervals up to 51 years and older. The highest percentage of respondents can be found in the age group 25 to 30 years.

In terms of the race distribution, the highest percentage of participants can be found in the white race group.

An analysis of the language distribution, the highest percentage of respondents is amongst the Afrikaans speaking group, with secondly that of the English group and thirdly the Tswana group.

A more or less equal distribution can be found when the male and female respondents are compared with each other.

\section{Measuring instrument}

The measuring instrument (Employment Equity Questionsnaire) consists of two parts. The first part consists of the different items that the respondents had to react upon and the second part contains the biographic information of the respondent. The questions in the instrument requires from respondents to indicate their feelings regarding the Employment Equity process within their organisation. The questionnaire, excluding biographical questions, consists of 146 questions. In some instances, the questionnaires were tailored to suit company specific requirements and/or included additional information. In order to ensure homogeneity, the different questionnaires were compared with each other and the non-generic items removed. Only the 41 generic questions that were posed to all the participating companies were used in the comparison.

This is a new instrument, of which the validity and reliability has not been tested. On face value, the instrument covers the domain of Employment Equity practices as indicated in the Act. The results of this study will furthermore assist in the identification of those industries being more conducive to the implementation of the Employment Equity Act.

\section{Procedure}

In order to guarantee authenticity, the questionnaires have been handed over to pre-identified responsible personnel in each industry to be distributed amongst participants. Instructions on the completion of the questionnaire were given to address any uncertainties. The identified person, adhering to principles of confidentiality and anonymity, collected the completed question-naires and handed it over to the compilers of the questionnaire.

\section{RESULTS}

The analysis of the data was constructed in two different phases. In the first phase factor analyses were conducted, followed by an iterative item analysis.

First phase of the data analysis

A first and second level factor analysis, followed by an iterative item analysis was conducted to 'purify' the construct "employment equity practices".

First level factor analysis

A Kaiser-Meyer-Olkin Measure of Sampling Adequacy (MSA) was executed in order to assess the suitability of the inter-correlation matrix for factor analysis. These results are portrayed in Table 2. It is clear from the obtained MSA and the Chi-square value that a factor analysis could be conducted.

In order to negate the possible effects of differential item skewness that could result in the creation of artefactors, a factor analysis as proposed by Schepers (1992), was performed. During the first level analysis, the 41 generic items were intercorrelated (41 x 41 matrix), upon which eigenvalues were calculated. In accordance with Kaiser's (1961) criterion, five eigenvalues larger than unity were postulated. These five factors explain about $53 \%$ of the variance in the factor space. The eigenvalues of the unreduced item inter-correlation matrix are reflected in Table 3.

TABLE 2

KMO AND BARTLETT'S TEST FOR THE FIRST LEVEL FACTOR ANALYSIS

\begin{tabular}{lrr}
\hline \multicolumn{2}{l}{ Kaiser-Meyer-Olkin Measure of Sampling adequacy } & 0,976 \\
\hline Bartlett's Test of & Approx. Chi-Square & 100624,4 \\
Sphericity & df & 820 \\
& Sig. & 0,000 \\
\hline
\end{tabular}

TABLE 3

EIGENVALUES OF THE UNREDUCED ITEM INTER-CORRELATION MATRIX

\begin{tabular}{|c|c|c|c|}
\hline \multirow[b]{2}{*}{ Root } & \multicolumn{3}{|c|}{ Initial eigenvalues } \\
\hline & Eigenvalues & $\%$ of Variance & Cumulative \% \\
\hline 1 & 16,125 & 39,329 & 39,329 \\
\hline 2 & 2,145 & 5,232 & 44,561 \\
\hline 3 & 1,485 & 3,623 & 48,184 \\
\hline 4 & 1,162 & 2,809 & 50,993 \\
\hline 5 & 1,133 & 2,763 & 53,766 \\
\hline 6 & 0,994 & 2,425 & 56,181 \\
\hline 7 & 0,916 & 2,234 & 58,415 \\
\hline 8 & 0,902 & 2,199 & 60,613 \\
\hline 9 & 0,827 & 2,018 & 62,632 \\
\hline 10 & 0,819 & 1,997 & 64,829 \\
\hline 11 & 0,783 & 1,910 & 66,539 \\
\hline 12 & 0,706 & 1,723 & 68,262 \\
\hline 13 & 0,697 & 1,701 & 69,963 \\
\hline 14 & 0,667 & 1,626 & 71,591 \\
\hline 15 & 0,636 & 1,551 & 73,142 \\
\hline 16 & 0,627 & 1,529 & 74,671 \\
\hline 17 & 0,591 & 1,442 & 76,113 \\
\hline 18 & 0,585 & 1,428 & 77,541 \\
\hline 19 & 0,551 & 1,344 & 78,884 \\
\hline 20 & 0,549 & 1,340 & 80,225 \\
\hline 21 & 0,539 & 1,316 & 81,540 \\
\hline 22 & 0,487 & 1,189 & 82,729 \\
\hline 23 & 0,476 & 1,161 & 83,890 \\
\hline 24 & 0,461 & 1,125 & 85,015 \\
\hline 25 & 0,452 & 1,101 & 86,117 \\
\hline 26 & 0,447 & 1,091 & 87,208 \\
\hline 27 & 0,435 & 1,061 & 88,269 \\
\hline 28 & 0,417 & 1,016 & 89,285 \\
\hline 29 & 0,411 & 1,002 & 90,287 \\
\hline 30 & 0,402 & 0,980 & 91,267 \\
\hline 31 & 0,393 & 0,958 & 92,225 \\
\hline 32 & 0,378 & 0,922 & 93,147 \\
\hline 33 & 0,372 & 0,907 & 94,053 \\
\hline 34 & 0,363 & 0,885 & 94,938 \\
\hline 35 & 0,339 & 0,826 & 95,764 \\
\hline 36 & 0,337 & 0,821 & 96,585 \\
\hline 37 & 0,318 & 0,775 & 97,360 \\
\hline 38 & 0,304 & 0,742 & 98,102 \\
\hline 39 & 0,276 & 0,673 & 98,775 \\
\hline 40 & 0,265 & 0,646 & 99,421 \\
\hline 41 & 0,237 & 0,579 & 100,000 \\
\hline Trace & 41,00 & & \\
\hline
\end{tabular}


An inter-correlation of the five subscores (SS) were performed, utilising Pearson's correlation coefficient. According to Healey (1990, p. 319) Pearson's correlation coefficient "is an index of the strength of the linear relationship between two variables", where a value of 0,00 is indicative of no linear relationship and a value of 1,00 indicates a perfect linear relationship. Coefficients approaching 0,00 can therefore we described as "weak" compared to those approaching 1,00 as "strong". It is thus of interest to note that the coefficients of the different factors manifest in descending order. From this table there is a statistical significant correlation between all five factors at the 0,01 level. The highest correlations have been reported between the first three factors, ranging from factor 1 and factor $2(r=0,812)$, factor 1 and factor $3(r=0,783)$, and between factor 2 and factor 3 $(r=0,707)$. The results are reflected in Table 4 .

TABle 4

INTER-CORRELATION MATRIX OF SUBSCORES (SS)

\begin{tabular}{lccccc}
\hline & SS 1 & SS 2 & SS 3 & SS 4 & SS 5 \\
\hline SS 1 & 1 & 0,812 & 0,783 & 0,564 & 0,381 \\
SS 2 & 0,812 & 1 & 0,707 & 0,522 & 0,326 \\
SS 3 & 0,783 & 0,707 & 1 & 0,471 & 0,329 \\
SS 4 & 0,564 & 0,522 & 0,471 & 1 & 0,473 \\
SS 5 & 0,381 & 0,326 & 0,329 & 0,473 & 1 \\
\hline
\end{tabular}

All Correlations are significant at the 0,01 level (2-tailed)

Second level factor analysis

For purposes of the second level factor analysis, the KaiserMeyer-Olkin Measure of Sampling Adequacy and the Bartlett's test of sphericity was performed on the inter-correlation matrix of the subscores. The results are reflected in Table 5. This matrix was also deemed suitable for further factor analysis.

TABLE 5

KMO AND BARTLETT'S TEST FOR THE SECOND LEVEL FACTOR ANALYSIS

\begin{tabular}{lrr}
\hline \multicolumn{2}{l}{ Kaiser-Meyer-Olkin Measure of Sampling adequacy } & 0,813 \\
\hline Bartlett's Test of & Approx. Chi-Square & 12985,91 \\
Sphericity & df & 10 \\
& Sig. & 000 \\
\hline
\end{tabular}

Once again, eigenvalues were calculated and only one factor with an eigenvalue larger than unity was postulated as displayed in Table 6. A single factor was extracted (see Table 7) that explained $64 \%$ of the variance in the factor space. The results are displayed in Table 6 and 7.

TABLE 6

EIGENVALUES OF THE UNREDUCED INTER-CORRELATION MATRIX OF SUBSCORES

\begin{tabular}{cccc}
\hline Root & Eigenvalues & $\begin{array}{c}\text { Initial eigenvalues } \\
\text { \% of Variance }\end{array}$ & Cumulative \% \\
\hline 1 & 3,202 & 64,048 & 64,048 \\
2 & 0,658 & 17,162 & 81,210 \\
3 & 0,4 & 9,662 & 90,871 \\
4 & 0,290 & 5,803 & 96,674 \\
Trace $=$ & 0,166 & 3,326 & 100,000 \\
\hline
\end{tabular}

TABLE 7

FACTOR LOADINGS OF SUBSCORES

\begin{tabular}{ccc}
\hline & Factor $\mathbf{1}$ & $\mathbf{h}^{\mathbf{2}} \mathbf{j}$ \\
\hline SS1 & 0,934 & 0,872 \\
SS 2 & 0,847 & 0,717 \\
SS 3 & 0,808 & 0,653 \\
SS 4 & 0,639 & 0,408 \\
SS 5 & 0,453 & 0,205 \\
\hline
\end{tabular}

Iterative item analyses yielded a Cronbach Alpha of 0,959. It needs to be noted that the Cronbach Alpha slightly increased to 0,963 with the exclusion of 12 items from the iterative item analysis. This however resulted in only 29 items being retained. For the purpose of this study, all 41 items were retained in the scale as displayed in Table 8.

TABLE 8

Item STATISTICS OF THE EMPloyment Equity QUeSTionNaire

\begin{tabular}{|c|c|c|c|c|}
\hline Item & Mean Score & $\begin{array}{c}\text { Standard } \\
\text { Deviation }\end{array}$ & Reliability Index & $\begin{array}{l}\text { Item - Test } \\
\text { Correlation }\end{array}$ \\
\hline Q6 & 2,630 & 0,807 & 0,382 & 0,474 \\
\hline Q84 & 2,901 & 0,806 & 0,289 & 0,359 \\
\hline Q12 & 2,882 & 0,791 & 0,534 & 0,674 \\
\hline Q11 & 2,847 & 0,743 & 0,418 & 0,562 \\
\hline Q4 & 3,113 & 0,797 & 0,520 & 0,651 \\
\hline Q1 & 2,875 & 0,875 & 0,003 & 0,689 \\
\hline Q7 & 2,524 & 0,893 & 0,630 & 0,705 \\
\hline Q8 & 2,641 & 0,862 & 0,546 & 0,634 \\
\hline Q10 & 2,563 & 0,838 & 0,644 & 0,768 \\
\hline Q14 & 2,825 & 0,808 & 0,595 & 0736 \\
\hline Q15 & 2,285 & 0,905 & 0,605 & 0,668 \\
\hline Q16 & 2,950 & 0,666 & 0,303 & 0,455 \\
\hline Q17 & 2,547 & 0,889 & 0,620 & 0,698 \\
\hline Q19 & 2,608 & 0,856 & 0,629 & 0,734 \\
\hline Q20 & 3,279 & 0,726 & 0,238 & 0,329 \\
\hline Q26 & 2,671 & 0,844 & 0,613 & 0,726 \\
\hline Q27 & 3,069 & 0,738 & 0,259 & 0,351 \\
\hline Q30 & 2,836 & 0,754 & 0,528 & 0,700 \\
\hline Q32 & 2,810 & 0,738 & 0,486 & 0,659 \\
\hline Q34 & 2,833 & 0,729 & 0,499 & 0,658 \\
\hline Q37 & 2,850 & 0,783 & 0,512 & 0,653 \\
\hline Q38 & 2,797 & 0,787 & 0,295 & 0,374 \\
\hline Q76 & 2,720 & 0,802 & 0,499 & 0,623 \\
\hline Q41 & 3,012 & 0,715 & 0,348 & 0,486 \\
\hline Q45 & 2,662 & 0,806 & 0,578 & 0,717 \\
\hline Q46 & 2,703 & 0,782 & 0,588 & 0,751 \\
\hline Q94 & 2786 & 0,734 & 0,391 & 0,532 \\
\hline Q48 & 2,786 & 0,782 & 0,529 & 0,676 \\
\hline Q54 & 2,561 & 0,870 & 0,638 & 0,733 \\
\hline Q55 & 2,653 & 0,819 & 0,616 & 0,752 \\
\hline Q56 & 2,785 & 0,794 & 0,561 & 0,707 \\
\hline Q57 & 2,761 & 0,756 & 0,383 & 0,506 \\
\hline Q58 & 2,561 & 0,843 & 0,616 & 0,731 \\
\hline Q59 & 3,050 & 0,695 & 0,308 & 0,444 \\
\hline Q60 & 2,745 & 0,833 & 0,613 & 0,736 \\
\hline Q63 & 2,645 & 0,806 & 0,590 & 0,732 \\
\hline Q65 & 2,274 & 0,871 & 0,472 & 0,542 \\
\hline Q71 & 2,822 & 0,826 & 0,571 & 0,691 \\
\hline Q81 & 2,959 & 0,637 & 0,265 & 0,416 \\
\hline Q82 & 2,933 & 0,657 & 0,278 & 0,423 \\
\hline Q9 & 2,622 & 0,815 & 0,520 & 0,637 \\
\hline
\end{tabular}

Cronbach Alpha = 0,959 
It can thus be stated that this Employment Equity Questionnaire measured employment equity practices consistently and reliably.

Second phase analysis of the data

During the second phase, inferential statistics were conducted. Mean scores on employment equity practices are presented in Table 9.

TABLE 9

COMPARISON OF COMPANY MEAN SCORES ON EMPLOYMENT EQUITY PRACTICES

\begin{tabular}{lccc}
\hline Company & Mean & Standard deviation & N \\
\hline Electonic media & 2,9679 & 0,31496 & 1549 \\
Banking & 2,6276 & 0,49855 & 1970 \\
Vehicle manufacturing & 2,9113 & 0,37440 & 166 \\
Retails & 2,7968 & 0,37356 & 70 \\
Chemical & 3,1035 & 0,38467 & 52 \\
Education & 2,9037 & 0,31423 & 138 \\
Information technology & 2,9450 & 0,45142 & 783 \\
Total & 2,8174 & 0,45573 & 4728 \\
\hline
\end{tabular}

An univariate analysis of variance (ANOVA) was conducted to assess whether different companies from various industries responded differently to the employment equity questionnaire. This yielded an F-ratio $(\alpha=0,05, d f=6 ; 4721)=115,428$ as depicted in Table 10.

TABLE 10

\section{ANOVA: TEST FOR SIGNIFICANCE OF MEAN SCORE DIFFERENCES}

\begin{tabular}{lcccccc}
\hline Source & $\begin{array}{c}\text { Type III } \\
\text { sum of } \\
\text { squares }\end{array}$ & Df & $\begin{array}{c}\text { Mean } \\
\text { square }\end{array}$ & F-ratio & P(F) & $\begin{array}{c}\text { Partial } \\
\text { Eta } \\
\text { squared }\end{array}$ \\
\hline Corrected model & 125,5977 & 6 & 20,933 & 115,428 & 0,000 & 0,128 \\
Intercept & 8336,353 & 1 & 8336,35 & 45969 & 0,000 & 0,907 \\
Comp & 125,597 & 6 & 20,933 & 115,428 & 0,000 & 0,128 \\
Error & 856,147 & 4721 & 0,181 & & & \\
Total & 38511,20 & 4728 & & & & \\
Corrected total & 981,744 & 4727 & & & & \\
\hline
\end{tabular}

The results of the Levene test showed that error variances were significantly different between companies, therefore the Dunnett statistics were interpreted in the post hoc comparisons. In order to eliminate the effect of the difference in sampling size, the range was squared and yielded a Partial Eta squared of 0,128 . At least $12,8 \%$ of the variance in differences between companies can thus be explained by means of employment equity practices. This is shown in Table 10.

During the post hoc tests, multiple comparisons were executed. Each company's (I) mean score was compared with of the other companies' (J) means scores to determine the mean difference (I minus J). The mean differences are regarded as significant at the 0,05 level. An analysis of the results indicates that the banking industry, with the exclusion of the retail industry, differs significantly when compared to the rest of the industries. The vehicle manufacturing industry in comparison with the education and IT industries are the only industry that yielded a significant score of 1,000. The results are shown in Table 11.
TABLE 11

Multiple Comparison according to THE DUNNETT T3 POST HOC TESTS

\begin{tabular}{|c|c|c|c|c|}
\hline Company (I) & Company (J) & $\begin{array}{c}\text { Mean difference } \\
(\mathrm{I}-\mathrm{J})\end{array}$ & Standard error & $\mathbf{P}$ \\
\hline \multirow{6}{*}{$\begin{array}{l}\text { Electronic } \\
\text { media }\end{array}$} & Banking & 0,3403 * & 0,1379 & 0,000 \\
\hline & Vehicle & 0,0566 & 0,3014 & 0,727 \\
\hline & Retail & 0,1711 * & 0,4536 & 0,007 \\
\hline & Chemical & $-0,1356$ & 0,5394 & 0,257 \\
\hline & Education & 0,0642 & 0,2792 & 0,377 \\
\hline & IT & 0,0229 & 0,1801 & 0,991 \\
\hline \multirow[t]{6}{*}{ Banking } & Electronic media & $-0,3403^{*}$ & 0,01379 & 0,000 \\
\hline & Vehicle & $-0,2837^{*}$ & 0,03115 & 0,000 \\
\hline & Retail & $-0,1692$ & 0,04604 & 0,009 \\
\hline & Chemical & $-0,4759$ * & 0,05451 & 0,000 \\
\hline & Education & $-02762 *$ & 0,02901 & 0,000 \\
\hline & IT & $-0,3174^{*}$ & 0,01966 & 0,000 \\
\hline \multirow{6}{*}{$\begin{array}{l}\text { Vehicle } \\
\text { manufacturing }\end{array}$} & Electronic media & $-0,0566$ & 0,03014 & 0,727 \\
\hline & Banking & $0,2837^{*}$ & 0,03115 & 0,000 \\
\hline & Retail & 0,1145 & 0,05327 & 0,498 \\
\hline & Chemical & $-0,1922$ & 0,06075 & 0,044 \\
\hline & Education & 0,0075 & 0,03950 & 1,000 \\
\hline & IT & $-0,0337$ & 0,03324 & 1,000 \\
\hline \multirow[t]{6}{*}{ Retail } & Electronic media & $-0,1711$ * & 0,04536 & 0,007 \\
\hline & Banking & 0,1692 * & 0,04604 & 0,009 \\
\hline & Vehicle & $-0,1145$ & 0,05327 & 0,498 \\
\hline & Chemical & $-0,3067^{*}$ & 0,06956 & 0,001 \\
\hline & Education & $-0,1070$ & 0,05205 & 0,578 \\
\hline & IT & $-0,1482^{*}$ & 0,04747 & 0,049 \\
\hline \multirow[t]{6}{*}{ Chemical } & Electronic media & 0,1356 & 0,05394 & 0,257 \\
\hline & Banking & 0,4759 * & 0,05451 & 0,000 \\
\hline & Vehicle & 0,1922 * & 0,06075 & 0,044 \\
\hline & Retail & 0,3067 * & 0,06956 & 0,001 \\
\hline & Education & 0,1998 * & 0,05968 & 0,026 \\
\hline & IT & 0,1585 & 0,05573 & 0,115 \\
\hline \multirow[t]{6}{*}{ Education } & Electronic media & $-0,0642$ & 0,02792 & 0,377 \\
\hline & Banking & 0,2762 * & 0,02901 & 0,000 \\
\hline & Vehicle & $-0,0075$ & 0,03950 & 1,000 \\
\hline & Retail & 0,1070 & 0,05205 & 0,578 \\
\hline & Chemical & $-0,1998^{*}$ & 0,05968 & 0,026 \\
\hline & IT & $-0,0412$ & 0,03124 & 0,986 \\
\hline \multirow[t]{6}{*}{ IT } & Electronic media & $-0,0229$ & 0,01801 & 0,991 \\
\hline & Banking & 0,3174 * & 0,01966 & 0,000 \\
\hline & Vehicle & 0,0337 & 0,03324 & 1,000 \\
\hline & Retail & $0,1482^{*}$ & 0,04747 & 0,049 \\
\hline & Chemical & $-0,1585$ & 0,05573 & 0,115 \\
\hline & Education & 0,0412 & 0,03124 & 0,986 \\
\hline
\end{tabular}

* The mean difference is significant at the 0,05 level

From these results the estimated marginal means for groups in homogenous subsets, based on Type III sum of squares and an Alpha of 0,05 , for each of the five factors were calculated. The results obtained, showed that the banking industry is the only one of the industries that stands independently within the first subset. The education and vehicle manufacturing industries share positions within the second subset. The chemical industry is once again the only one independently in the third subset. The retail, IT and electronic industries overlap into both of the subsets. The results point to the fact that the banking industry has yielded the least positive results on the Employment Equity Questionnaire and the chemical industry the most positive. The 
retail industry's position is significantly closer to that of the banking industry than to that of the education, vehicle manufacturing, IT and the electronic media. This industry can therefore also be regarded as not yielding positive results when measured on the Employment Equity Questionnaire. The IT and electronic media share their position in the second subset with that of the third subset and can be regarded as having more positive perceptions of the employment equity practices within their respective industries. Table 12 displays the estimated Marginal means Homogenous subsets.

\section{TABLE 12}

ESTIMATED MARGINAL MEANS HOMOGENOUS SUBSETS

\begin{tabular}{lcccc}
\hline Company & $\mathrm{N}$ & \multicolumn{2}{c}{ Subset } \\
& & $\mathbf{1}$ & $\mathbf{2}$ & $\mathbf{3}$ \\
\hline Banking & 1970 & 2,6276 & & \\
Retail & 70 & 2,7968 & 2,7968 & \\
Education & 138 & & 2,9037 & \\
Vehicle manufacturing & 166 & & 2,9113 & \\
IT & 783 & & 2,9450 & 2,9450 \\
Electronic media & 1549 & & 2,9679 & 2,9679 \\
Chemical & 52 & & & 3,1035 \\
Sig. & & 0,082 & 0,075 & 0,131 \\
\hline
\end{tabular}

Shaded values are unique in the subset

\section{DISCUSSION}

The population that was used in the study was not selected randomly. The results can therefore not be generalised to include all industries in South Africa, nor to similar companies within a specific industry. This aspect represents the most important limitation of the study.

The analysis of the data was conducted in two phases. During the first phase, first and second level factor analyses, followed by iterative item analyses were conducted to 'purify' the construct "employment equity practices". Iterative item analyses on the obtained scale yielded a Cronbach Alpha of 0,959. It could therefore be stated that the Employment Equity questionnaire measured employment equity practices consistently and reliably.

During the second phase of the data analysis, inferential statistics were conducted. A univariate analysis of variance (ANOVA) was conducted and yielded a F-ratio $(\alpha=0,05, d f=$ $6 ; 4721)=53,907$. During the post hoc tests, multiple comparisons were executed, indicating which of the industries differs significantly from the others. The statistical results that were performed indicate that the Employment Equity Questionnaire indeed discriminates between the marginal means of the various companies. There are thus statistical significant differences between the various industries' employment equity practices as perceived by the respondents. These findings support the discriminant validity of the Employment Equity Questionnaire.

In the three subsets that were produced, four of the companies differ significantly from the rest of the companies. The most significant discrepancy is however between the banking and chemical companies. The company from the chemical industry scored the highest marginal mean (most positively) on the Employment Equity Questionnaire. The results from the company from the banking industry reflect the least positive response on the Employment Equity Questionnaire. Companies from the Education and Vehicle Manufacturing industries share a centre position. The companies from the Retail, Information Technology and Electronic media industries could be linked to more than one of the subsets. In the light of the obtained results, the discriminant validity of the Employment Equity questionnaire can be confirmed.

Although this study succeeded in establishing the discriminant validity of the Employment Equity Questionnaire, there are areas of improvement that need to be considered to increase the content and face validity of the instrument. The limitations of the employment equity questionnaire centre first and foremost around the item and response scale construction. By addressing the problem of double-barrelled, leading and ambiguous questions, the quality of responses and eventually the statistical data can be improved. By utilising a response scale format that is more conducive towards providing reliable responses, a more normal distribution curve will be attained.

Against this backdrop, the following suggestions are put forward. Evaluated against the guidelines of Schepers (1992) previously referred to, both the item format and response scale format of the questions can be improved. To pose questions and not statements as suggested by Schepers, will provide normal response distributions. In this instance, items were posed as statements, resulting in nearly bimodal distributions. The four-point response scale that was used is considered to be restrictive and not conducive for the explanation of variance and consequently also not for factor analyses. All response categories used in this study were anchored as illustrated in Figure 3.

\begin{tabular}{|c|c|c|c|c|}
\hline $\begin{array}{c}\text { Strongly } \\
\text { disagree }\end{array}$ & Disagree & Neutral & Agree & Strongly agree \\
\hline 1 & 2 & 3 & 4 & 5 \\
\hline
\end{tabular}

Figure 3: Example of a Likert response scale where all categories are anchored

This response format however poses a few problems. According to Torgenson (1958) and Schepers (1992), the quality of an equal interval scale ("ordered categories for which the intervals between all ranks are equal" - Bailey, 1982, p.128) fades away when more than two points on the scale are anchored. Swart et al. (1999) argued that an intensity scale could be used as an alternative to this item format, where only the two extreme points are anchored.

Swart et al. (1999) indicated that the problem with the use of the Likert scale is the tendency of participants to choose the two most extreme statements, generally known as the tendency to agree, without proper consideration of the content of the statement. A solution to the problem would be to translate the positive and negative statements in the form of questions. It is therefore suggested that questions, combined with equal interval response scales are used. An example is indicated in Figure 4 .

\begin{tabular}{|c|c|c|c|c|}
\hline Never & & & & Always \\
\hline 1 & 2 & 3 & 4 & 5 \\
\hline
\end{tabular}

Figure 4 : Suggested response scale to be used in an employment equity questionnaire

It is furthermore suggested that the formulation of some of the items are adapted in order to improve the quality of the response on the specific item. Statistical results have indeed proved that 
certain of the items were problematic. Lower item-test correlations were reported on these items. It would have been beneficial if pilot studies were conducted first, before the final compilation of the questionnaire. This step would have highlighted the "problem" statements where difficulty in answering is experienced. Such questions could have been rephrased, eradicating the problems experienced in item construction. In this regard Bailey indicated: "pretesting is the final stage in questionnaire construction - and one of the most important" (1982, p.150).

Examples of such questions are subsequently discussed.

\section{Double-barrelled questions}

A number of "double-barrelled questions", where two or more questions are posed as one, were identified. Stating questions in this format poses a problem in providing an answer. Bailey (1982, p.115) stated that such questions "lead to hesitation and indecision on the part of the respondent (and) frustration builds up particularly if there is more than one such a question".

The following example is highlighted to illustrate this point:

Question 45 "I am happy with the amount of time, money and energy the company is spending on employee development".

The aforementioned statement can be posed as three separate questions, giving rise to more worthy and valid responses.

\section{Leading questions}

Examples of leading questions were found. Bailey (1982, p.121) stated that items should be carefully structured in order to "minimize the probability of biasing the respondent's answer by leading him or her and thus artificially increasing the probability of a particular response".

The following statement is an example of a leading item that might influence the answer.

Question 27. "I am sure that all language, gender and cultural groups can perform equally well in supervisory and management positions, provided that they are given the right training".

\section{Ambiguous questions}

Bailey warned against ambiguous questions as "different respondents interpret a question in different ways" (1982, p.116). An example of an ambiguous question is listed below:

Question 7 "Management takes action to train suitable employees to become supervisors and managers".

Given the fact that the Employment Equity questionnaire was presented to various companies and biographically different respondents, it can be expected that different interpretations of the term "suitable" will arise. As the focus is on Employment Equity practices the term "designated groups" could have been substituted for the word "suitable".

Suggestions for employers, who consider using a questionnaire to measure employment equity within their companies, would be to have a profound look at the construction of the questionnaire. Questions should be asked if the construction of the items and responses are in accordance with the principles and criteria underpinning questionnaire construction. Careful scrutiny of both the item and response scale format being used in the questionnaire is essential, as this will ultimately impact the quality of the data generated. Enquiries on the processes that were followed in the questionnaire construction should be made (e.g. were pilot studies conducted?)

Additional development of the existing questionnaire is suggested in order to refine it and align it with the steps as proposed by Schepers (1992). Suggestions for further research could include the use of an experimental design where the effect of response distribution on different question formats is examined.

\section{REFERENCES}

Bailey, K.D. (1982). Methods of social research (2nd edition). New York: The Free Press.

Carrell, M.R., Elbert, N.F., Hatfield, R.D., Grobler, P.A., Marx, M. \& Van Der Schyf, S. (1998). Human resource management in South Africa. South Africa: Prentice Hall.

Christensen, E.W. (1999). An exploration of industry, culture and revenue growth. Available from: http://www.findarticels.com/ (Accessed 08 August 2002)

Commission for Employment Equity: Annual report. (2001). Available from: http://www.labour.gov.za/docs/legioslation/ eea/index.html (Accessed 08 November 2001)

De Beer, H. \& Clow, L. (2001). Creativity, a new culture. HR Focus, 19 (8), 32.

Debating Employment Equity. (2002). Available from: http://www. csls.org.za/dw/art3c.html (Accessed 29 August 2002).

Ernst, E. (2000). Skills development. Pretoria: Kitskopié.

Gerber, P.D., Nel, P.S. \& Van Dyk,, P.S. (1995). Menslike hulpbronbestuur (3e uitgawe). Halfwayhouse: Southern Publishers.

Healy, J.F. (1990). Statistics, a tool for social research (2nd edition). California: Wadsworth Publishing Company.

Hellriegel, D., Slocum, J.W. \& Woodman, R.W. (1998). Organizational behavior ( $8^{\text {th }}$ edition). Ohio: South-Western College Publishing.

Horwitz, L. \& Ferleger, L. (1980). Statistics for social change. Boston: South End Press.

Human, L. (2000). Equity and efficacy: The business case for Employment Equity. Talk delivered at the IPM Eastern Cape Regional Conference - 21 June 2000.

Human, L. (2002). Diversity management. Upside workshops. Available from: http://www.ancordynamics.co.za/diversity.html (Accessed 29 August 2002)

Human, L. \& Dentin, M. (1997). The management of people. Available from: http://www.sabpp.co.za/news/199710_ managepeople.htm (Accessed 29 August 2002).

Irani, Z., Sharp, J.M. \& Kagioglou, M. (1997). Improving business performance through developing a corporate culture. The TQM Magazine, 9 (3), pp. 206-216.

Ivancevich, J.M. \& Matteson, M.T. (1996). Organizational behavior and management (4th edition). Chicago: Irwin.

Kaiser, H.F. (1961). A note on Guttman's lower bound for the number of common factors. British Journal of Statistical Psychology, 14 (1), p.1.

Kruger, T. \& Roodt, G. (2003-in the press). Hofstede's VSM-94 revisited: Is it reliable and valid? SA Journal of Industrial Psychology, 29 (2), pp. 75-82.

Marquardt, M.J. (1998). The Global Advantage. Texas: Gulf Publishing Company.

Pemberton, E. (1933). A technique for measuring the optimum rating scale for opinion measures. Sociology and Social Research, (17), pp. 470-472.

Republic of South Africa (1997). Basic Conditions of Employment Act No. 75 of 1997, Government Gazette, Volume 390, No. 18491.

Republic of South Africa (1998). Employment Equity Act No. 55 of 1998, Government Gazette, Volume 450, No. 22209.

Republic of South Africa (1995). Labour Relations Act No. 66 of 1995, Government Gazette, Volume 366, No. 16861.

Republic of South Africa (1995). South African Qualifications Authority Act No. 58 of 1995, Government Gazette, Volume 364, No. 16725

Republic of South Africa (1988). South African Skills Development Act No. 97 of 1998, Government Gazette, Volume 401, No. 19420. 
Rousseau, D.M., (1989). Psychological and implied contracts in organisations. Employee Responsibilities and Rights Journal, 2 (2), pp. 121-139.

Sacht, J. (2001). Human Resource systems health check. EquitySkills Development News, 2 (4), pp. 1-6.

Schepers, J.M. (1992). Toetskonstruksie: Teorie en praktyk. Johannesburg: Randse Afrikaanse Universiteit.

Swart, C., Roodt, G. \& Schepers, J.M. (1999). Itemformaat, differensiële itemskeefheid en die faktorstruktuur van 'n selfvoltooiingsvraelys. SA Journal of Industrial Psychology, 25 (1), pp. 33-34.

Stewart, T.A. (2001). Intellectual Capital: Ten years later, how far we've come. Fortune, May 28, pp. 1-3.
Strümpfer, D. (2001) Available from: http://www.edulink.rau.ac.za (Accessed 29 August 2001).

Swanepoel, B.J., Erasmus, B.J., Van Wyk, M.W. \& Schenk, H.W. (2000). South African Human Resource Management: Theory and Practice (2nd edition). South Africa: Juta \& Co Ltd.

Symonds, P.M. (1924). On the loss of reliability in rating due to coarseness of the scale. Journal of Experimental Psychology, 7, pp. $456-460$.

Torgenson, W.S. (1958). Theory and methods of scaling. New York: Wiley.

Watkins, G. (2002). Gender equality - the forgotten component in Employment Equity initiatives. Equity-Skills News \& Views Newsletter, 1 (2), pp. 17-25. 